J. Anim. Prod. O.A.R., 9, No. 1, pp. 43-48 (1969).

\title{
A DISCUSSION OF SOME FACTORS LIMITING THE PRODUCTIVITY OF BERSEEM CLOVER (TRIFOLIUM ALEXAVDRINUM L.)
}

\author{
HoKaMED S. RADWAN (1)
}

Some of the factorg limiting the productivity of berseem clover in V.A.R. are discussed in light of the results of research on this crop.

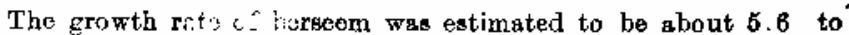
$8.5 \mathrm{~g}^{2} \mathrm{~m}^{2}$ : day indicating low efficiency in dry matter production compared with other forages. This is ascribed to the slow development of leaf ares before the first cutting and to deviation of the attained leaf aree from an optimum leaf ares inder. This ouggeats careful atudies of the factora affecting lesf ares development especially oowing date and the seeding rate.

The narrow differences in productivity among local varietien offert no hope for incressing total forage production by selection among varietief, Also, success in developing improved strains seems de. pendent on the detection of variantis within varietien or varietsil croabes.

The quslity of eeed tued for aowing playe a major role in limiting the total production of bergeem fornge. This is evidenced by the large variation among farmers seed lota of the fahl variety. The stats is urged to apply seed certification messures to insure the distribr. tion of good quality, seed.

Berseem clover is the principal forage legume in U.A.R. sown in an area of about 2.44 million faddans (i) of which 1.3 million is considered a catch crop yielding one or two cuts before sowing cotton. In the rest of the area, it is grown as a regular crop for soiling, silage and hay.

The total forage produced from berseem is estimated as 41 million tons ; the feeding value of which makes for more than $70 \%$ of the total food units from available feeding stuffs. The sum of locally produced animal feeds can barely be sufficient for the existing livestock population, if rational use of berseem forage is excercised. However, tho rising demand for animal products by the growing population calls for an increase in livestock and poultry production to offset the deficit in their products. This necessitates the search for methods of increasing the amount of feed stuffs especially berseem. The object of this report is to discuss some of the major factors limiting the productivity of berseem in U.A.R.

\section{The efficiency of berseem in dry matter production.}

If it is assumed that an average of $I .5$ cuts are taken from the catch crop and 3.5 cuts from the regular berseem crop, an average forage yield of 7.1 tons per cut is obtained. For a regular crop of 4 cuts, the average yield is

(1) Agronomy Dept., Fac. of Agric., Cairo University. 
then 28.4 tons per faddan or about 4.0 tons of dry matter for a growing season. of more than 170 days. It means that the average growth rate for berseem plants is $5.6 \mathrm{~g} / \mathrm{m}^{2} /$ day. Record crops from the Miskawy variety go up to 6.0 tons per faddan yielding a growth rate of $7.5 \mathrm{~g} / \mathrm{m}^{2} /$ day. This shows. that the daily growth rate of berseem is surprisingly low compared with other forage species (Table 1). According to theoretical calculations ( ${ }^{(3)}$ a crop canopy is expected to have a daily growth rate of about $77 \mathrm{~g} / \mathrm{m}^{2}$. Although most plant species have mean daily growth rates which are $20-25 \%$ of this potential $\left({ }^{3}\right)$, we see that berseem accumulates only about $10 \%$ of it.

The large inefficiency of berseem in dry matter production may be ascribed to;1) slow development of photosynthetic leaf area before the first cut especially in late sowings, and 2) the application of seeding rates which result in leaf area indices (leaf area per unit land surface) higher or lower than an optimum for maximum production. Data obtained by the author $\left({ }^{5}\right)$ show that increasing the seeding rate of the Fahl variety results in an increase in leaf area and forage yield up to a certain limit beyond which both leaf area and yield begin go drop (Table 2). Farid et al. $\left({ }^{2}\right)$ concluded that the rate of seeding used by farmers (26-32 kgs/F) is much greater than the $20 \mathrm{kgs}$ rate they found optimum for highest yield from Miskawy berseem. Although these workers took no measurement on leaf area, their data imply that the rate of seeding affects forage yield through its effect on leaf area. However, the various factors affecting leaf area development in this crop need to be carefully studied.

\section{Differences in Productivity among local varieties.}

The identity of local varieties of berseem is rather vague. Except for Wafeer ( ${ }^{1}$ ), the history of the other varieties, namely, Miskawy, Khadrawi, Saidi and Fahl is not exactly kmown. Fahl produces only one cutting since. it is incapable of regrowth after cutting. The other varieties yield from 3 to 6 cuttings depending upon the date of sowing.

A study has been launched by the author ot asses the relative merits of these varieties as produceres of dry matter. The 5 varieties were sown in field plots at Giza in a latin square design. Dry matter production and leaf area at intervals were measured. The detailed results of this work will be published elsewhere. The data presented in Table 3 are, however, sufficient to indicate that the multicut varieties are essentially alike in their productivity. The Wafeer variety did not excell in forage yield as has been claimed by Raafat, Abou-Raya, and Sultan ( ${ }^{\circ}$ ).

The high yield of the Fabl variety in comparison with the first cutting from multicut varieties appears to be the result of its peculiar growth type. Fahl plants were shown to accumulate more dry matter in their tops and less in their stubble and roots. Total dry matter production is similar for all varieties. 
The quality of berseem seed.

The majority of farmers produce their own clover seed, the rest purchase uncertified seed from local dealers. A low premium is paid for good quality seed with the result that seed of poor quality is generally sown. The extent of weeds in clover fields attest to the poor seed quality.

The yielding ability of farmers seed lots appears to vary a great deal. This is evidenced by the results obtained for the Fahl variety (4). From various districts of the republic, 37 commercial seed lots of the Fahl variety were coliected and compared with standard Fahl seed supplied by the forage crops section of the Ministry of Agriculture. A randomized block design was used and the trial was conducted at both Giza and Sakha. A summary of the results of both trials is given in Table 4. It is evident from these results that commercial lots differ widely in their productivity and general characteristics especially in relation to the ability to regrow after cutting. The outstanding faet is that most lots yield less than or equal to the standard Fahl seed. This indicates that the use of por quality seed plays a major role in reducing total production. It is also worth noting that some lots gave exceptionally better yields than the standard variety. These lots could serve as breeding material for varietal improvement.

TABLE 1.-DRY MATTER YIRLD AND DAILY GROWTH RATES FOR SOME FORAAE CROPS

\begin{tabular}{r|c|c|c|c|c}
\hline \multicolumn{1}{c|}{ Crop } & Area & $\begin{array}{r}\text { Yield } \\
\text { T/A }\end{array}$ & $\begin{array}{c}\text { Season } \\
\text { days }\end{array}$ & $\begin{array}{c}\text { Growth } \\
\text { rate }\end{array}$ & Ref. \\
\hline Sweet Sorghum .... & U.A.R. & 10.0 & 120 & 19.9 & - \\
Sudan grass ..... & Calif. & 13.3 & 160 & 18 & 3 \\
Alfalfa ....... & Calif. & 14.5 & 250 & 13 & 3 \\
Berseem clover .... & U.A.R. & 4.0 & 170 & 6.6 & - \\
Miskawy ... & & $6.0^{*}$ & 190 & 7.5 & 6 \\
Fahl .... & & $4.14^{*}$ & 130 & 7.5 & 6 \\
\hline
\end{tabular}

\footnotetext{
* Record yield,
} 
TABLE 2.-THE EMHECT OF SEEDING RATE ON LEAF AREA INDEX (LAI) AT HARVEST AND FORAGE YIELD OF FAHL BERSEEM*.

\begin{tabular}{|c|c|c|c|c|}
\hline & \multicolumn{4}{|c|}{ Seeding rate, seeds $/ \mathrm{m}^{2}$} \\
\hline $\mathrm{LAI} \cdots \ldots \ldots$ & 2.25 & 3.11 & 4.03 & 4.01 \\
\hline Green Yield (Tons $/ \mathbf{F}) \ldots$ & 6.63 & 9.15 & 11.50 & 11.73 \\
\hline
\end{tabular}

- Averaged for seada of different aize.

TABLE 3.-AVRRAge PERForMaYGe OF LOCAL VARLETIES OF BER3BEM

\begin{tabular}{|c|c|c|c|c|c|c|}
\hline Charsoter & Cut & $F_{a h l}$ & Miskawy & Khadrawy & Saidi & Wafeer \\
\hline \multirow[t]{3}{*}{ Forage yield $(\dot{\mathrm{T}} . / \mathrm{F})$} & 1 & 11.5 & 8.2 & 9.4 & 7.4 & 7.2 \\
\hline & 2 & - & 8.4 & 9.5 & 9.6 & 9.6 \\
\hline & 3 & 一 & 4.9 & 6.0 & 5.6 & 4.9 \\
\hline \multirow[t]{2}{*}{ Leafiness $(\%)^{*}$} & 1 & 25.4 & 31.0 & 30.2 & 31.6 & 32.5 \\
\hline & 3 & - & 17.0 & LI? 1 & 15.1 & 21.5 \\
\hline Stubble $\left(\mathrm{g} \cdot / \mathrm{m}^{2}\right)^{*} \ldots$ & 1 & 25.6 & 84.8 & 76.4 & 84.4 & 91.2 \\
\hline $\operatorname{Roots}\left(\mathrm{g} \cdot(\mathrm{m})^{*}\right.$ & 1 & 24.4 & 30.0 & 27.2 & 31.2 & 32.4 \\
\hline
\end{tabular}

- Dry weight basis. 
TABLE 4.-RANGE OF PERFORMANCE OF 37 COMMERCIAL SEED LOTS OF FAHL BERSHEM GROWN AT 2 LOCATTONS COMPORED WITH STANDARD FAHL SEED

\begin{tabular}{|c|c|c|c|c|}
\hline \multirow{2}{*}{ Charaeter } & \multicolumn{2}{|c|}{ Gizo } & \multicolumn{2}{|c|}{ Sakhe } \\
\hline & $\begin{array}{l}\text { Commercial } \\
\text { Lots }\end{array}$ & $\underset{\text { Mean }}{\text { Standard }}$ & $\begin{array}{c}\text { Commercial } \\
\text { Lots }\end{array}$ & $\begin{array}{c}\text { Standard } \\
\text { Mean }\end{array}$ \\
\hline Forage yield (Tons./F) . . . & $7.2-13.5$ & 11.4 & $8.1-19.9$ & 9.1 \\
\hline Dry patter $(\%) .$. & $9.8-13.8$ & 9.8 & $8.6-12.9$ & 10.7 \\
\hline Regrowth rate* . . . & $1-4$ & 2 & $1-5$ & 2 \\
\hline Leafine $(\%)$ & $26.1-43.4$ & 28.2 & $15.0-26.8$ & 16.7 \\
\hline Heading date* ...... & $2 \sim 36$ & 6 & I6-39 & 23 \\
\hline
\end{tabular}

- A gosie of 1 to $\delta ; 1$ for no regrowth and 5 for abundant regrowth after cutting.

- Daya aftar Marob 1.

\section{REFEREN CES}

EL-SsIFX, A.M.(1956). "Production of new atrain of berseem",-F.A.O. of the D.N. Working party on the development of grazing and fodder resources of the Near East. First Meeting, Cairo.

Farid, N. I., Grobital, K.M. ard Ramurat A.M. (1968). The effect of methods of aowing with different rates of ooding on fodder and seed production of Berseem clover.-Agr. hes. Rev. $46: 46-50$.

Looms, R.S. AND WuLLams W.A. (1963). Maximum grop productivity : An estimate Crop Sci. $3: 67-72$.

RADW $\Delta \mathrm{N}$, M.S. (1969). Variation among commeroial seed lots of the Fahl variaty of beraeem (Trifolium Alexandrinum L.) Proc. \$ixth Arab. Sci. Cong., Damascus.

- (1969). The influence of seed size and seeding rate on the growth and yield of the Fahl variety of bergeom clover (Trifolium Alexandrimum L.) Proc. Sizth Arab. Sci. Cong., Damascus.

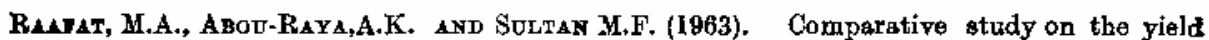
and nutritive analysis of the three varieties of Egyptian clover (Trifolium Alexandrimum). at different cuta.-Proc. of the 2nd Anim. Prod. Conf., Cairo Vol. 2.

Yenr Boox of Agric.-Eonomick, Ministry of Agrio, U.A.R. (1966). 


\section{منأقثة بعض العوامل المحدة لانتاجية البرسبيم المصرى}

\section{1المُصص}

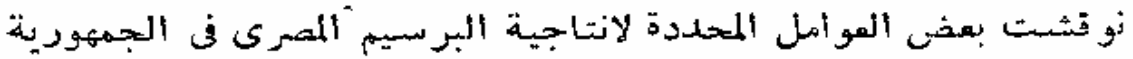

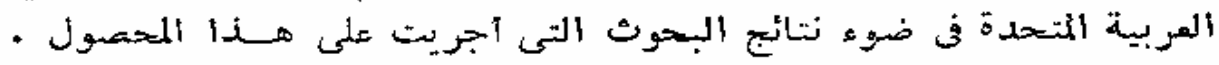

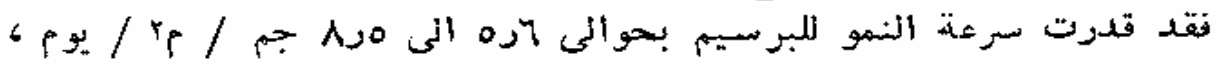

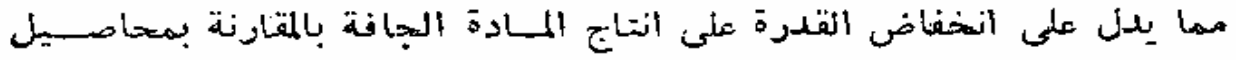

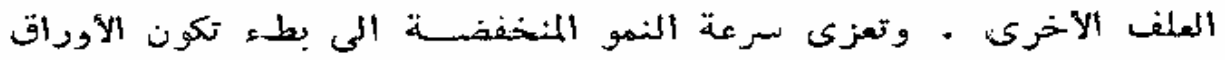

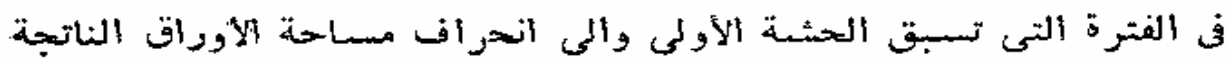

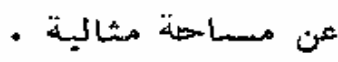

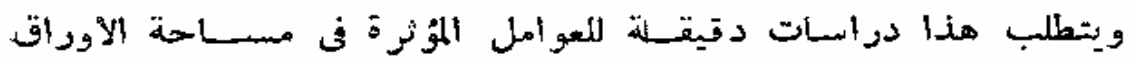

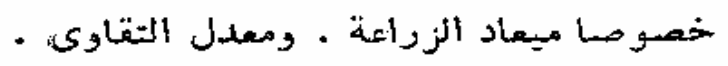

وبخصوص انتاجية الأصناف المهالية فان قلة الفروق المقاد الوراثية بين

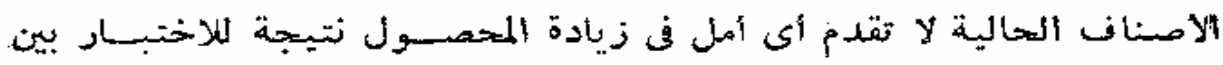

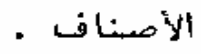

أما جودة التقاوى الممبتخفمة في النزراعة فانها تلمب دورا هاما فيتحديد

$$
\text { - الانتاج الكنى البرسيمة البتاويم }
$$

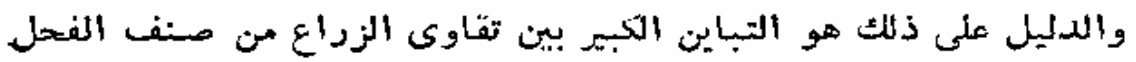

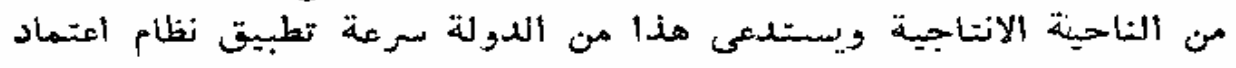

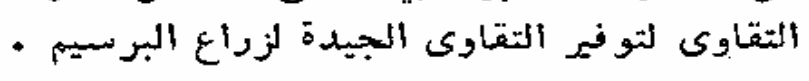

